\title{
Second generation succession in cross-cultural family business alliance: A case study
}

\author{
B.Y. Pratama \\ Diponegoro University, Semarang, Indonesia
}

\begin{abstract}
This research offers empirical insights on family business succession, a complex and challenging issue seen from cognition, structure, culture, and resource aspects, and identifies patterns related to the succession process structure. An overarching model to evaluate resources such as social capital and successor behavior, sustainability, and development of the cross-cultural family business alliance was developed and used as a reference that influences the succession process's pattern and length. Insights into the succession process contribute to a layered understanding of the cross-cultural family alliances' patterns and business behavior. The connected patterns explain the role of predecessors and successors changing over time during the transition process. The succession process is a formal structured process for defining the business framework, and these practices comprehend various outcomes relevant to the stages of generational ownership and the dynamics of family relationships. In conclusion, this research proposes an agenda for advancing research on cross-cultural family business alliance.
\end{abstract}

\section{INTRODUCTION}

The discussion about laws, norms, and values embedded in a cultural context shapes how a company is managed and directed. Certain institutional arrangements offer opportunities to advance the field of management. A family business research is gaining legitimacy gradually as an independent field of study. Over time, some family businesses have begun to lead to strategic alliances involving two or more families of different cultures. In current management research, a research related to the family business and strategic alliances is considered a well-established and prestigious field.

Joint ventures can be a rewarding experience, even though there are many challenges involved, and adding a cross-cultural element is one of the challenges. Collaborative partnerships have long been researched and applied. They range from micro to multinational enterprises and pursue multiple goals. The structure of a family business alliance with an ordinary business is distinctly different. In control of a family business alliance's management and strategic decisions, the family has the dominant position. In practice, the family business is usually governed by two main components: holding a large proportion of equity ownership and involving the dominant managerial control over the business (Luan et al., 2018).

In managerial control, where the founding family has dominance, the business activities are expected to develop with each alternation of generations. Founders can play a critical role in business succession to avoid risks. Business alliances of families with different cultures can reach a vulnerable point at the time of succession. Therefore, proper governance mechanisms are essential in this process. Different attitudes and views toward strategic decisions often arise in succession. The transfer of ownership is seen as an isolated event at the last stage of the transition process and simultaneously acts as an instrument for empowering new leaders.

Family businesses tend to prefer internal candidates over external candidates for succession (Schell et al., 2018). In this case, management control and monitoring mechanisms are deemed necessary by the previous generation to prepare a business transition to the successor (Shen $\& \mathrm{Su}$, 
2017). The family business founder's social capital is a valuable resource and a critical success factor because it has an impact on the performance of the family business in the future (Pearson et al., 2008). Resource management in many family businesses is considered complicated, as family members often participate simultaneously in family and business interactions at home and work (Kidwell et al., 2018).

This phenomenon is a serious concern because every company, especially the one with a crosscultural alliance business model, has unique challenges and risks. Identifying the difference between management and ownership succession needs to be the focus of more research on the family business. Considering the phenomenon mentioned above, innovative research that can be used as a reference for business succession is needed, especially in a family business context. One of the efforts to identify the problems is a case study. This approach is an in-depth investigation of contemporary phenomena in real contexts, especially when the boundaries of the context are not clear and may involve important contextual conditions (Yin, 2017). With this approach, strategies that can be used as a reference for the next generation's succession can be described correctly.

\section{LITERATURE REVIEW}

Succession or regeneration in family businesses is one of the most challenging things to do (Merwe et al., 2009). Passing down a company to the next generation is a challenge (Zareie, 2011). It is because succession is a sensitive topic for several companies (Dhewanto \& Tirdasari, 2012). Constraints in regeneration and succession planning are quite challenging in family businesses (Milan, 2012). Only about $40 \%$ of family businesses can pass the baton of leadership to the next generation, which makes succession a significant concern (Whatley, 2011). Different viewpoints between generations and the existence of a conflict in the family are some of the obstacles to be overcome for successful succession or regeneration (Merwe et al., 2009).

One of the significant factors in determining the continuation of a family business is the success of the planning process and strategy in the succession. Because the easier it is, the more successful will be this transformation in deciding the success and long-term sustainability of these generations (Merwe et al., 2009). The inability to manage the succession process can result in a decrease in the effectiveness of the business and can lead to bankruptcy (Milan, 2012).

\section{METHODOLOGY}

This research employs a qualitative research method. The qualitative research method was used to gain a better understanding of the experiences of participants with a certain life context (Arcidiacono et al., 2009). In addition, the qualitative research method emphasized the exploration of individual experiences, describes phenomena, and builds theories (Cope, 2014). Therefore, this research investigated and revealed the judgments of a person (participant) and their relationship to their work and experiences (Arcidiacono et al., 2009).

The choice of the qualitative research method depends on the research questions asked and which method will be studied (Yin, 2009). A case study was chosen because there are many 'how' questions posed in a social phenomenon, and an in-depth description of the phenomenon is needed (Yin, 2009). The purpose of this case study is not to generalize the results, but to prove the existence of a theory (Woodside \& Wilson, 2003). In conclusion, the case study method was chosen because an in-depth understanding of the life phenomenon of the succession process in a family business is needed.

The data were collected from respondents or participants from different inter-ethnic (Overseas Chinese and Javanese) family business alliances in Central Java. The overview of succession focuses on four main elements: cognition, which includes the strategy and learning process; structure, which includes interactions with employees; culture, which includes norms and values; and resources, which include status and knowledge. The family businesses that become participants in this research 
were family businesses that have a total of more than two hundred employees. The participants in this research were the first and second generations of family businesses of each ethnicity. They are the successors of the company or are being prepared to become the next generation of the company.

\section{RESULTS AND DISCUSSION}

Four respondents were examined in this research, the four of whom were successors and prospective successors in their respective companies. The four respondents in the research were referred to as Respondent 1 (R1), Respondent 2 (R2), Respondent 3 (R3), and Respondent 4(R4). In this research, it was found that R1 and R2 were carrying out a succession process in their family businesses, while R3 and R4's succession was still in progress. R1 and R2 have sat as the top leaders of their family businesses. Currently, R1 and R2 felt the need to carry out the succession process. R2 and $\mathrm{R} 3$ are the second generation because the founders are still active in the business as the highest decision makers.

In profile, the four respondents have several similarities and differences. The respondents studied were the second generation of each family of Overseas Chinese and Javanese ethnics. All respondents were male. Another similarity between the two successors was that they have got a bachelor's degree.

The difference between the four respondents lies in ethnicity, experiences within the company, and position in the company. Two respondents (R1 and R3) were of Chinese descent, and the other two respondents (R2 and R4) were of Javanese ethnicity. Based on experiences in the company, $\mathrm{R} 1$ and R2 have formed an alliance for more than twenty years. Meanwhile, R3 and R4 have been placed in management only for one year as managers.

The process of succession or regeneration of family companies in Semarang was carried out differently between the companies. Companies owned by R1 and R 2 are family companies that have launched a succession process. Meanwhile, the purpose of the succession carried out by R1 and R2 was seen from the elements of cognition, structure, culture, and resources of the successor in maintaining sustainability and developing the business alliance.

\section{CONCLUSION}

Cognition includes strategies and learning processes of companies, where the highest decision maker in the family company is a member of the owner's family. Decisions related to the company's strategic plan and investment rest with the core family members, namely, the founder, husband/wife of the founder, and the children of the founder. It is also what that differentiates family companies from non-family companies.

The founder assesses the structure of the company and guides the next generation regarding dealing with subordinates and superiors. The founder expects the successor of the company to show a professional attitude. In family companies, the board of directors and top management are limited to family members.

The culture that exists in the family company, including the problem-solving method, will influence the decision making of the company. Acting in a professional manner and not differentiating family and non-family workers are other characteristics of a family company. Values from family cultures with ethnic differences are instilled in the succession process. Family members outside the family have the same position as other employees and have the authority, rights, and obligations in accordance with their respective jobs.

The family company was founded with a variety of resources, especially human resource management (HRM). The status and knowledge of the next generation in running a business cannot be separated from social values. Choosing a business sustainability strategy is important and needs to be mastered by the successor. The company's status, including social values such as empowering 
the surrounding community and making employees the main assets, is a characteristic of family companies that other companies usually do not have.

From this research, several things were found in connection with the succession process in three companies in Semarang:

a. Succession planning;

b. Succession process time;

c. Motivation driving successor's interest;

d. Selection of successors in the company;

e. Training given in the succession process;

f. The relationship between successors and previous generations (incumbent);

g. The stages in the succession process;

$\mathrm{h}$. The changes brought by the second generation; and

i. The evaluation of the succession process.

\section{REFERENCES}

Arcidiacono, C., Procentese, F. \& Di Napoli, I. 2009. Qualitative and Quantitative Research: An Ecological Approach. International Journal of Multiple Research Approaches 2009 Vol.3, 163-176.

Cope, D.G. 2014. Methods and Meanings: Credibility and Trustworthiness of Qualitative Research. Oncology Nursing Forum Vol. 41, No. 1 January 2014.

Dhewanto, W. \& Tirdasari, N.L. 2012. Family Business Succession in Indonesia: A Study of Hospitality Industry. Asia Pacific Business Innovation and Technology Management, Procedia - Social and Behavioral Sciences 57 (2012) 69-74.

Kidwell, R.E., Eddleston, K.A. \& Kellermanns, F.W. 2018. Learning bad habits across generations: How negative imprints affect human resource management in the family firm. Hum. Resour. Manag. Rev. 28, $5-17$.

Luan, C.-J., Chen, Y.-Y., Huang, H.-Y. \& Wang, K.-S. 2018. CEO succession decision in family businesses A corporate governance perspective. Asia Pac. Manag. Rev. 23, 130-136.

Merwe, S., Venter E. \& Ellis, S.M. 2009. An Exploratory of Some of Determinants of Management Succession Planning in Family Business. Management Dynamics Volume 18 No. 4.

Milan, H. 2012. Succession Planning and Generational Transition: The Greatest Challenges for Family-owned Businesses. Journal of Eastern Europe Research in Business and Economics, 1-11.

Pearson, A.W., Carr, J.C. \& Shaw, J.C. 2008. Toward a theory of familiness: A social capital perspective.

Entrep. Theory Pract. 32, 949-969.

Schell, S., Hiepler, M. \& Moog, P. 2018. It's all about who you know: The role of social networks in intra-family succession in small and medium-sized firms. J. Fam. Bus. Strategy 9, 311-325.

Shen, N. \& Su, J. 2017. Religion and succession intention-Evidence from Chinese family firms. J. Corp. Finance 45, 150-161.

Woodside, A.G. \& Wilson, E.J. 2003. Case Study Research Methods for Theory Building. The Journal of Business \& Industrial Marketing Vol.18 2003493.

Whatley, L. 2011. A New Model for Family-Owned Business Succession. Organization Development Journal Vol. 29 No. 4, Winter 2011.

Yin, R.K. 2009. Case Study Research: Design and Methods 4th ed. Applied Social Research Methods Series Vol.5. Sage Publications: California.

Yin, R.K. 2017. Case study research and applications: Design and methods. Sage Publications: California.

Zareie, M. 2011. Analysis of Effective Factors on Family Business Transition to the Next Generations in Iran: Strategic Management Perspective. International Conference on Financial Management and Economics vol.11. 